\title{
PELATIHAN PEMBUAT AN PROBIOTIK PADA PETANI PEMBUDIDAYA IKAN DESA PEUNAGA PAYA KECAMATAN MEUREUBO KABUPATEN ACEH BARAT
}

\section{PROBIOTICS PRODUCTION TRAINING FOR FISH FARMERS IN PEUNAGA PAYA VILLAGE MEUREUBO DISTRICT WEST ACEH REGENCY}

\author{
Fitria Rahmayanti ${ }^{1}$ \\ ${ }^{1}$ Program Studi Akuakultur, Fakultas Perikanan dan IImu Kelautan, Universitas Teuku Umar \\ Korespondensi: fitriarahmayanti@utu.ac.id
}

\begin{abstract}
ABSTRAK
Meningkatnya kebutuhan masyarakat terhadap ikan lele konsumsi di Kabupaten Aceh Barat membuat pembudidaya lele kesulitan dalam memenuhi kebutuhan tersebut. Desa Peunaga Paya Kecamatan Meureubo sebagai salah satu desa penghasil ikan lele mengalami kendala dalam memenuhi permintaan pasar akan ikan lele. Sulitnya memenuhi permintaan pasar salah satunya disebabkan oleh hasil produksi yang tidak optimal. Hal ini disebabkan karena kurangnya pengetahuan dan kemampuan tentang teknik budidaya ikan lele yang tepat sehingga manajemen budidaya yang dijalani selama ini masih belum baik. Selain itu, petani pembudidaya ikan di desa tersebut masih menggunakan teknologi konvensional dimana mereka belum memahami pentingnya penambahan nutrisi pada pakan untuk mempercepat masa panen dengan hasil yang optimal. Kendala-kendala yang mereka hadapi selama ini adalah masih menggunakan teknologi tradisional karena kurangnya pengetahuan dan kemampuan mitra, ikan mudah terserang penyakit, ikan yang dibudidayakan sering mengalami penurunan nafsu makan, kualitas air budidaya buruk, dan laju pertumbuhan ikan lambat sehingga memperlama masa panen dan biaya produksi meningkat. Dalam rangka menbatu memecahkan permasalahan petani pembudidaya ikan di desa tersebut maka dilaksanakanlah kegiatan pengabdian kepada masyarakat dengan memberikan penyuluhan tentang teknik budidaya ikan yang tepat dan praktik pembuatan probiotik sebagai nutrisi tambahan pada pakan dengan memanfaatkan bahan-bahan yang murah dan mudah didapatkan.
\end{abstract}

Kata kunci: probiotik, pelatihan, budidaya ikan, Peunaga Paya

\section{ABSTRACT}

The Increasing of community needson catfish consumption in West Aceh district is making it more diffucult for catfish farmers tomeet the need. Peunaga Paya Village as one of the catfish producing villages in Meureubo District constrained in meeting the market demand for this product. Not optimal production was one of the causes for that problem. This is due to their knowledge and ability about catfish farming techniques was lacking so their current culture management was still not good. In addition, fish farmers still use conventional technology so they have not understood the importance of adding nutrients in fishfeed to accelerate the harvest period with optimal results. So far, the obstacles they faced are using traditional technology due to lack of partners knowledge and ability, fish susceptible to disease, cultivated fish often experience decreased appetite, poor of water quality, and slow fish growth rate so the harvest time more longerand the cost production increases. In order to solve the problems, it is implemented the community service activities by giving counseling about the proper fish farming techniques and the practice of making probiotics as an additional nutrient to fishfeed withcheap and easy to find ingredients.

Keywords: probiotics, training, fish culture, Peunaga Paya

\section{PENDAHULUAN}

Peningkatan pertumbuhan budidaya air tawar didasarkan pada potensi sumberdaya alam yang dimiliki oleh Indonesia, salah satu komoditas air tawar yang memiliki potensi untuk dikembangkan adalah ikan lele. Hal ini didasarkan karena ikan 
lele memiliki tingkat perimintaan yang cukup tinggi yaitu sekitar \pm 500.000 ekor/minggu (Arief, 2014). Dengan adanya peningkatan permintaan ikan lele mendorong masyarakat untuk melakukan kegiatan budidaya ikan lele, budidaya ikan lele merupakan salah satu bentuk manajemen usaha, dimana manajemen adalah proses perencanaan, pengorganisasian, pengarahan, dan pengawasan usaha-usaha para anggota organisasi dan penggunaan sumberdaya organisasi lainnya untuk mencapai tujuan usaha (Handoko, 2009).

Khususnya di Kabupaten Aceh Barat, permintaan akan Lele Sangkuriang semakin meningkat dibandingkan dengan beberapa tahun yang lalu. Pelaku usaha rumah makan, catering dan lainnya memasok ikan ini dari para Agen Penampung. Menurut agen, mereka terkadang mengalami kesulitan dalam memenuhi permintaan pasar karena produksi Ikan Lele Sangkuriang dari Petani Pembudidaya Ikan belum maksimal.

Petani pembudidaya di Kabupaten Aceh Barat khususnya di Kecamatan Meureubo Desa Peunaga Paya belum mendapatkan hasil yang maksimal dari produksinya selama ini. Hal ini disebabkan karena kurangnya kemampuan petani pembudidaya ikan di desa ini dalam hal teknik pembesaran ikan. Petani Pembudidaya Ikan di Desa Peunaga Paya juga belum mendapatkan ilmu terbaru yang berhubungan dengan nutrisi tambahan untuk ikan yang dibudidaya.

Probiotik didefinisikan sebagai mikroorganisme hidup non-patogenik, yang jika dikonsumsi dalam jumlah tertentu akan memberikan efek menguntungkan bagi inang (host) (FAO/WHO, 2001). Lebih lanjut Jin et al. (1997) melaporkan bahwa Probiotik merupakan bakteri-bakteri yang secara tradisional telah lama digunakan dalam bentuk makanan, mengandung baik bakteri hidup, bakteri mati maupun metabolitnya yang dalam kurun waktu lama terbukti aman. Manfaat probiotik pada unggas adalah menempatkan mikroorganisme yang menguntungkan dan menekan mikroorganisme yang merugikan, meningkatkan aktifitas enzim-enzim pencernaan dan menekan aktifitas enzim-enzim bakteri yang merugikan, memperbaiki sistem pencernaan, menekan produksi gas amonia, dan merangsang sistem pertahanan tubuh.

Menurut Food and Agriculture Organization/World Health Organization (FAO/WHO) (2001), idealnya strain probiotik seharusnya tidak hanya mampu bertahan melewati saluran pencernaan tetapi juga memiliki kemampuan untuk berkembang biak dalam saluran pencernaan, tahan terhadap cairan lambung dan cairan empedu dalam jalur makanan yang memungkinkan untuk bertahan hidup melintasi saluran pencernaan dan terkena paparan empedu. Selain itu probiotik juga harus mampu menempel pada sel epitel usus, mampu membentuk kolonisasi pada saluran pencernaan, mampu menghasilkan zat anti mikroba (bakteriosin), dan memberikan pengaruh yang menguntungkan inangnya. Syarat lainnya adalah tidak bersifat patogen dan aman jika dikonsumsi. Strain probiotik juga harus tahan dan tetap hidup selama proses pengolahan makanan dan penyimpanan, mudah diaplikasikan pada produk makanan, dan tahan terhadap proses psikokimia pada makanan (Prado et al., 2008).

Keberhasilan budidaya perikanan tercemin pada tingginya produksi serta rendahnya tingkat kematian. Penggunaan probiotik mampu memperbaiki kondisi perairan sehingga menjadi alternatif pembudidaya ikan saat ini. Probiotik adalah makanan tambahan (suplemen) berupa sel-sel mikroorganisme hidup yang memiliki pengaruh menguntungkan bagi hewan inang yang mengkonsumsinya melalui 
penyeimbangan flora mikroorganisme intestinal dalam saluran pencernaan (Irianto, 2003).

Probiotik berperan sebagai sumber nutrien dan enzim pencernaan. Beberapa penelitian membuktikan bahwa mikroorganisme mempunyai pengaruh yang menguntungkan dalam proses pencernaan pada hewan-hewan perairan yaitu, mikrobiota dapat berperan sebagai sumber makanan suplemen dan aktvitas mikrobia dalam saluran pencernaan dapat menjadi sumber vitamin dan asam amino essensial (Metges, 2000), dan mempengaruhi aktivitas pencernaan (Ghosh et al., 2008).

Kegiatan Pengabdian Kepada Masyarakat (PKM) dilakukan pada kelompok masyarakat yang bergerak di bidang budidaya pembesaran Ikan Lele Sangkuriang. Kelompok ini memulai usahanya pada tahun 2015. Anggota kelompok dari pembudidaya Lele Sangkuriang ini terdiri dari 12 orang yang sebagian besar adalah Pemuda Desa Peunaga Paya yang memiliki keinginan berwirausaha di Bidang Perikanan. Motivasi mereka menekuni usaha di Bidang Perikanan berawal dari potensi lahan yang ada di desa ini sangat mendukung untuk dilakukan usaha tersebut.

Kelompok pembudidaya yang merupakan mitra pada program ini sulit melakukan pengembangan usaha karena hasil produksi budidaya Ikan Lele masih jauh dari kata maksimal. Teknologi yang mereka gunakan juga masih tergolong tradisional dengan sarana dan prasarana yang masih minim. Selama ini mereka menjalankan usaha dengan mengandalkan sistem coba-coba karena mereka belum mengetahui manajemen budidaya yang baik dan benar.

Selama 2 tahun melakukan budidaya Ikan Lele Sangkuriang, mereka menghadapi banyak kendala. Kendala ini terjadi karena masih minimnya pengetahuan dan kemampuan mereka dalam melakukan budidaya Ikan Lele Sangkuriang. Berdasarkan hasil Focus Group Discussion (FGD) dengan kelompok pembudidaya dan pantauan di lapangan, masalah-masalah yang dihadapi oleh kelompok tersebut antara lain:

1. Masih menggunakan teknologi tradisional karena kurangnya pengetahuan dan kemampuan mitra.

2. Ikan yang dibudidayakan mudah terserang penyakit karena sistem imun yang menurun.

3. Ikan yang dibudidayakan mengalami kurang nafsu makan.

4. Pertumbuhan ikan lambat sehingga memperpanjang masa budidaya dan menyebabkan peningkatan biaya produksi seperti pakan.

5. Kualitas air yang buruk akibat dari sisa pakan yang terbuang (akibat dari menurunnya nafsu makan ikan).

Probiotik untuk budidaya ikan komersil banyak dijual di pasaran, namun harganya kurang terjangkau untuk petani pembudidaya skala kecil atau konvensional. harga probiotik komersil juga dapat meningkatkan biaya produksi. namun hal ini dapat diantisipasi dengan membuat sendiri probiotik dari bahan-bahan yang murah dan mudah didapat. Oleh karena itu, Pelatihan Pembuatan Probiotik dari Ragi dan Bakteri Asam Laktat (Rabal) Pada Kelompok Petani Pembudidaya Ikan Lele di Desa Peunaga Paya Kecamatan Meureubo Kabupaten Aceh Barat dirasa perlu dilakukan untuk meningkatkan kemampuan petani pembudidaya ikan di desa tersebut dan untuk meningkatkan hasil produksi ikan yang dibudidayakan. 
Kegiatan Pengabdian kepada Masyarakat ini bertujuan untuk meningkatkan kemampuan petani pembudidaya ikan tentang teknik pembesaran ikan yang efektif dan efesien dan meningkatkan kemampuan mereka agar mampu membuat probiotik sendiri dengan bahan-bahan yang murah dan mudah didapat sehingga aplikasinya dapat membantu meningkatkan produksi ikan yang dibudidaya secara optimal.

Melalui kegiatan pengabdian kepada masyarakat ini diharapkan dapat memperbaiki kesalahan-kesalahan pembudidaya tentang teknik budidaya yang selama ini mereka terapkan. Selain itu, diharapkan petani pembudidaya memiliki daya saing dan kemandirian dalam melakukan usaha budidaya ikan.

\section{METODE}

Kegiatan Pengabdian Kepada Masyarakat (PKM) ini dilakukan pada kelompok masyarakat yang bergerak di bidang budidaya pembesaran Ikan Lele Sangkuriang pada bulan Maret 2018. Anggota kelompok dari pembudidaya Lele Sangkuriang ini terdiri dari 12 orang yang sebagian besar adalah pemuda Desa Peunaga Paya yang memiliki keinginan berwirausaha di bidang perikanan. Metode pendekatan yang dilakukan pada kegiatan ini adalah dengan metode ceramah (penyuluhan) tentang teknik budidaya ikan lele yang efektif dan efisien dan praktikum/praktik langsung pembuatan probiotik RABAL serta aplikasinya pada pakan untuk meningkatkan produksi budidaya dan menyelesaikan masalah yang dihadapi.

Dalam kegiatan ini, probiotik yang dibuat adalah probiotik RABAL (Ragi dan Bakteri Asam Laktat). Adapun bahan-bahan yang digunakan adalah air bersih (9 liter), minuman Yakult (2 botol), ragi tape (1 buah), air kelapa tua murni (dari 1 buah kelapa), dan molase (3 tutup botol ditambah dengan $1 / 2$ liter air). Sedangkan alat-alat yang digunakan adalah jerigen ukuran 10 liter dan ember.

\section{HASIL DAN PEMBAHASAN}

Kegiatan Pengabdian Kepada Masyarakat ini telah dilaksanaka pada tanggal 13 dan 26 Maret 2018. Kegiatan yang dilakukan pada tanggal 13 Maret 2018 di Balai Desa Peunaga Paya diisi dengan kegiatan penyuluhan tentang teknik budidaya ikan lele dan pengenalan manfaat probiotik dalam kegiatan budidaya ikan lele. Selain itu, juga dilakukan praktik langsung pembuatan Probiotik RABAL. Sedangkan kegiatan yang dilaksanakan pada tanggal 26 Maret 2018 diisi dengan aplikasi langsung Probiotik RABAL pada saat pemberian pakan pada ikan lele di lokasi budidaya (kolam terpal milik petani pembudidaya).

\subsection{Penyuluhan Teknik Budidaya Ikan Lele dan Manfaat Probiotik}

Selama pelatihan kelompok pembudidaya ikan diberikan penyuluhan tentang teknik budidaya ikan yang baik dan benar. Adapun teknik-teknik budidaya yang dijelaskan meliputi pemilihan benih yang berkualitas, penebaran benih, teknik pemberian pakan, pengendalian hama dan penyakit dan manajemen kualitas air selama masa pemeliharaan. Selain itu petani pembudidaya diberikan juga pengetahuan dan pengenalan probiotik dan manfaatnya pada kegiatan budidaya ikan.

Pada kegiatan penyuluhan ini terlihat bahwa peserta antusias mengikuti dan aktif bertanya dan berdiskusi (Gambar 1.). Pertanyaan yang diajukan pada umumnya adalah tentang tingkat keselamatan hidup benih yang rendah, nafsu makan ikan yang menurun dan pertumbuhan yang lambat. Dari hasil diskusi ini dapat diketahui bahwa 
yang menjadi masalah utama dalam kegagalan budidaya ikan lele selama ini adalah petani pembudidaya tidak mengerti tentang teknik pemilihan benih unggul, teknik pemberian pakan yang benar, dan kurangnya pemahaman tentang nutrisi tambahan untuk meningkatkan laju pertumbuhan dan kesehatan ikan. Dari hasil penyuluhan yang dilakukan petani pembudidaya mulai memahami teknik budidaya yang benar dan menyadari kesalahan-kesalahan pada kegiatan pembesaran ikan yang selama ini mereka lakukan.

Selain itu petani pembudidaya di desa tersebut juga merasa terbantu dengan adanya ilmu baru tentang nutrisi tambahan berupa probiotik yang dapat diberikan selama masa pembesaran ikan sehingga mempercepat pertumbuhan ikan dan meningkatkan kesehatan ikan. Peserta juga semakin antusia karena probiotik ternya dapat dibuat sendiri dengan bahan-bahan yang murah dan mudah didapat (Gambar 4.)

Melalui penyuluhan ini masyarakat mendapatkan pengetahuan yang selama ini belum mereka dapatkan sehingga dapat meningkatkan kemampuan mereka di bidang perikanan budidaya. Menurut Darmansyah (2016), Pengembangan masyarakat merupakan kegiatan yang dilakukan bersama komunitas masyarakat dengan cara meningkatkan partisipasi aktif masyarakat dalam rangka memenuhi kebutuhan hidup dan penyelesaikan persoalan-persoalan yang dialami oleh komunitas masyarakat. Selain itu, kegiatan pengembangan masyarakat dapat berupa peningkatan keterampilan melalui pelatihan peningkatan kemampuan dalam mengolah sumber daya alam (Ihsan, 2002).

Mulyadi (2011) menyatakan bahwa pemberian probiotik yang mengandung Lactobacillus sp. dan Bacillus sp. dengan konsentrasi $108 \mathrm{sel} / \mathrm{mL}$ dapat meningkatkan pertumbuhan ikan patin (Pangasius hypophthalamus) dibandingkan tanpa probiotik. Nutrien yang seimbang akan menghasilkan pertumbuhan yang baik, dan pertumbuhan terjadi apabila ada kelebihan energi bebas setelah energi yang tersedia digunakan untuk pemeliharaan tubuh, metabolisme basal, dan aktivitas.

\subsection{Pelatihan Pembuatan Probiotik RABAL}

Pada kegiatan ini dilaksanakan pelatihan pembuatan probiotik RABAL dengan cara praktik langsung. Selama proses praktik pembuatan probiotik berlangsung juga diberikan penjelasan kepada peserta tentang fungsi dari bahan-bahan yang digunakan dalam pembuatan probiotik. Hal tersebut bertujuan agar peserta memahami bahwa masing-masing bahan saling berhubungan satu sama lain karena keberhasilan dari probiotik yang dibuat adalah dari kelengkapan bahan yang disediakan (Gambar 2 dan Gambar 4)

Bahan yang digunakan salah satunya adalah ragi dan bakteri Lactobacillus sp. yang berasal dari minuman Yakult. Bakteri Lactobacillus sp. yang terdapat pada Yakult dikultur untuk memproduksi bakteri baik dalam jumlah yang banyak sehingga dapat digunakan sebagai tambahan pada pakan ikan.

Selain bakteri Lactobacillus sp. bahan lain yang digunakan dalam pembuatan probiotik ini adalah ragi (yeast). Menurut Dwijoseputro (1988), ragi tape merupakan populasi campuran yang terdiri dari spesies-spesies genus Aspergilius, Saccharomyces, Candida, Hansenulla, dan bakteri Acetobacter. Selanjutnya Darwis dan Sukara (1989) menyatakan bahwa Fermentasi ialah proses baik secara aerob 
maupun anaerob yang menghasilkan berbagai produk yang melibatkan aktivitas mikroba atau ekstraknya dengan aktivitas mikroba terkontrol.

Ragi tape digunakan untuk pembuatan produk fermentasi seperti misal tape ketan dan tape singkong. Ragi tape berasal dari tepung beras yang dicampurkan dengan bahan-bahan lain sehingga dapat membantu dalam proses fermentasi. Di dalam ragi ini terdapat mikroorganisme yang dapat mengubah karbohidrat (pati) menjadi gula sederhana (glukosa) yang selanjutnya diubah lagi menjadi. Karbohidrat (pati) terfermentasi maka menghasilkan sejumlah besar asam laktat yang akan menurunkan nilai $\mathrm{pH}$ sehingga menimbulkan rasa asam.

Salah satu faktor penting dalam pertumbuhan bakteri adalah nilai $\mathrm{pH}$. Bakteri memerlukan suatu $\mathrm{pH}$ optimum untuk tumbuh optimal. Pengaruh $\mathrm{pH}$ terhadap pertumbuhan bakteri ini berkaitan dengan aktivitas enzim. Enzim dibutuhkan oleh bakteri untuk mengkatalis reaksi-reaksi yang berhubungan dengan pertumbuhan bakteri. Apabhila $\mathrm{pH}$ dalam suatu medium/lingkungan tidak optimal, maka akan menggangu kerja dari enzim-enzim tersebut, yang pada akhirnya akan mempengaruhi pertumbuhan bakteri itu sendiri (Pelczar dan Chan, 1986). Oleh karena itu, ragi perlu ditambahkan sebagai bahan pembuatan probiotik untuk membantu aktifitas fermentasi sehingga dapat meningkatkan kandungan nutrisi pada probiotik tersebut.

Bahan selanjutnya yang digunakan adalah molase atau tetes tebu dan air kelapa. Air kelapa mengandung gula, protein, asam-asam amino, bermacam-macam vitamin dan mineral (Woodroof, 1970), sehingga dengan kandungan nutrien yang relative lengkap tersebut, air kelapa mempunyai potensi yang baik untuk dimanfaatkan sebagai bahan dasar fermentasi asam-asam organik (Fardiaz et al., 1996). Bakteri penghasil asam laktat merupakan salah satu bakteri yang cenderung tertarik pada habitat yang mengandung gula seperti air kelapa dan bakteri ini akan memfermentasikan senyawa yang ada menjadi asam laktat (Madigan et al.,2000).

Penggunaan gula yang ada dalam substrat untuk pertumbuhan BAL ini dapat terlihat dengan meningkatnya kerapan sel BAL pada substrat. Pemecahan glukosa dalam sel BAL menghasilkan energi untuk aktivitas BAL akan menghasilkan senya-wa lain termasuk asam laktat. Asam laktat yang dihasilkan oleh BAL akan terseks-kresikan keluar sel dan akan terakumulasi dalam cairan fermentasi (Susanto, 2012).

\subsection{Aplikasi Probiotik Rabal dalam Pakan Ikan}

Probiotik yang dibuat pada saat praktik tidak dapat langsung digunakan atau diaplikasikan pada pakan ikan. Namun harus disimpan selama 7 hingga 10 hari untuk membiarkan proses fermentasi dan kultur bakteri berlangsung. Probiotik yang dibuat harus disimpan di ruangan yang tidak terkena sinar matahari dan setiap hari wadah penyimpanan probiotik harus dibuka sebentar untuk mengeluarkan uap hasil fermentasi kemudian ditutup rapat kembali.

Setelah 10 hari probiotik yang berhasil dicirikan dengan wangi (seperti wangi tape) dan warnanya lebih coklat dari warna awal. Probiotik yang telah berhasil dibuat tersebut dapat diaplikasikan pada pakan dengan cara memasukkan 2-3 tutup botol aqua probiotik kemudian dicampurkan dengan air sebanyak $1 / 2$ liter air dan langsung dapat disemprotkan pada pakan. Pakan yang disemprot tersebut diangin-anginkan sebentar sekitar 10-15 menit (bukan dikeringkan di bawah sinar matahari langsung) 
agar probiotik dapat menyerap ke dalam pakan. Kemudian pakan dapat langsung diberikan kepada ikan yang dibudidayakan (Gambar 5.)

\section{SIMPULAN}

Kesimpulan yang dapat diambil dari kegiatan pengabdian kepada masyarakat ini adalah sebagai berikut:

1. Penguasaan dan pemahaman tentang teknik budidaya ikan lele yang tepat dibutuhkan oleh petani pembudidaya ikan agar hasil produksi optimal.

2. Penambahan probiotik sebagai nutrisi tambahan pada pakan memiliki banyak keuntungan seperti nafsu makan meningkat, menjaga kesehatan ikan yang dibudidayakan sehingga tidak mudah terserang penyakit dan laju pertumbuhan ikan meningkat.

3. Probiotik yang dibuat secara mandiri dengan bahan-bahan yang mudah dan murah didapat dapat menekan biaya produksi dan hasil produksi optimal.

4. Secara umum tingkat pemahaman petani pembudidaya ikan tentang teknik pembesaran ikan dan informasi terkini di bidang budidaya perairan masih rendah.

\section{UCAPAN TERIMA KASIH}

Terima kasih kepada LPPM \& PM Universitas Teuku Umar yang telah memberikan izin untuk dilaksanakannya kegiatan pengabdian kepada masyarakat ini. Terima kasih kepada Kelompok Pembudidaya Ikan Desa Peunaga Paya Kecamatan Meureubo Kabupaten Aceh Barat dan berbagai pihak yang telah banyak membantu sehingga terlaksananya kegiatan pengabdian ini.

\section{DAFTAR PUSTAKA}

Arief M. 2014. Pengaruh Pemberian Probiotik Berbeda Pada Pakan Komersial Terhadap Pertumbuhan dan Efisiensi Pakan Ikan Lele Sangkurinag. Jurnal IImiah Perikanan Dan Kelautan. 6 (1): 1-7

Darmansyah A, Sulistiono, Nugroho T, Supriyono E. 2016. Pemberdayaan Masyarakat Melalui Pengembangan Budidaya Ikan Lele di Desa Balongan, Indramayu, Jawa Barat. Jurnal Agrokreatif IPB. 2(1): 8-16

FAO/WHO. 2001. Joint FAO/WHO Expert Consultation on Evaluation of Health and Nutritional Properties of Probiotics in Food Including Powder Milk with Live Lactic Acid Bacteria. Amerian Córdoba Park Hotel, Córdoba. Argentina.

Fardiaz, S., E.D. Nuraini, dan H. Kusumaningrum. 1996. Pemanfaatan AirKelapa untuk Produksi Minuman Sehat Anti Diare Melalui ProsesFermentasi Laktat. Buletin Teknologi dan Industri Pangan.7 (2): 47-53.

Ghosh, H., A. Shinha and C. Sahu. 2008. Bioaugmentation in the Growth and Water Quality of Livebearing Ornamental Fishes. Aquaculture International. 16: 393403.

Handoko H. 2009. Manajemen. BPFE. Yogyakarta.

Insan YN. 2002. Kajian Pengembangan Budidaya Laut (Pengaruhnya Terhadap Kesejahteraan Responden Pesisir) Studi Kasus Di Kelurahan Pulau Panggang Kab. Seribu.[Tesis]. Bogor (ID): Institut Pertanian Bogor. 
Jin LZ, Ho YW, Ali MA, Abdullah N, and S. Jalaludin. 1997. Probiotic in Poultry: Modes of Action. World's Poultry Science Journal. 53: 23-30

Madigan MT,Martinko JM, and Parker J. 2000. Biology of Microorganisme, Brock. NPrentice-Hall Inc. New Jersey.

Mulyadi AE. 2011. Pengaruh Pemberian Probiotik pada Pakan Komersil terhadap Laju Pertumbuhan Benih Ikan Patin Siam (Pangasius hypophthalamus). [Skripsi]. Fakultas Perikanan dan IImu Kelautan. Universitas Padjajaran. Jatinangor.

Prado FC, Parada JL, Pandey A, and Soccol CR. 2008. Trends in Non-Dairy Probiotic Beverages. Food Res. Int. 41: 111-123.

Woodroof JG. 1970. Coconut Prodution, Processing, Product. Avi Publishing Co. Inc. London.

\section{Gambar Kegiatan Pengabdian Kepada Masyarakat}

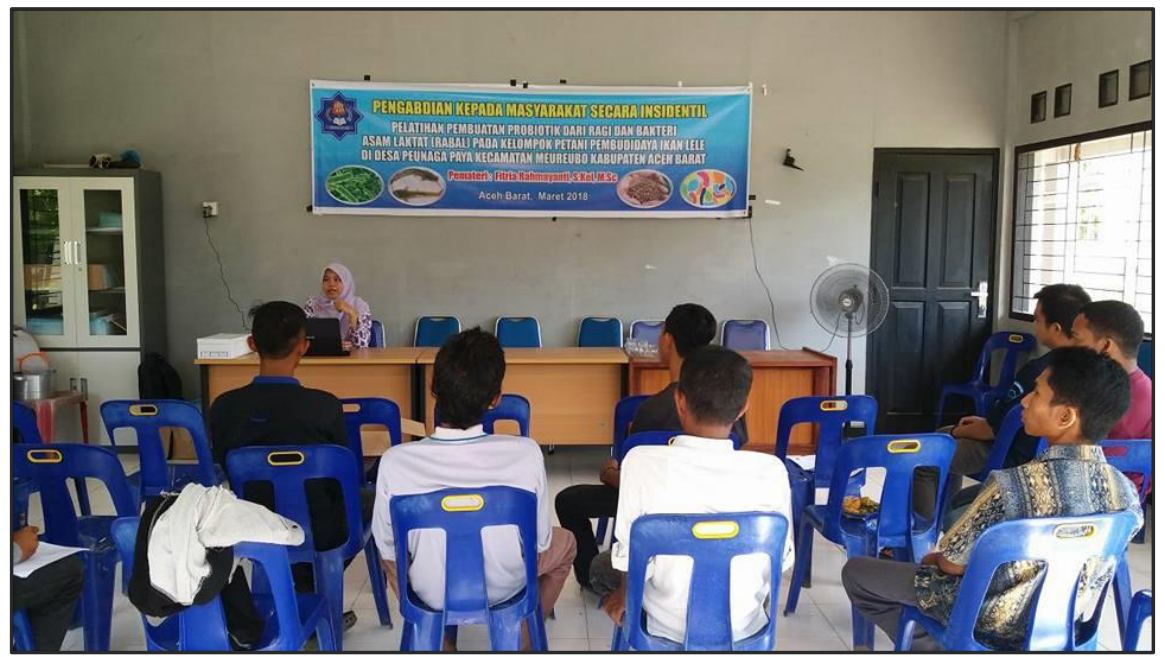

Gambar 1. Penyuluhan tentang Teknik Budidaya Ikan Lele yang tepat

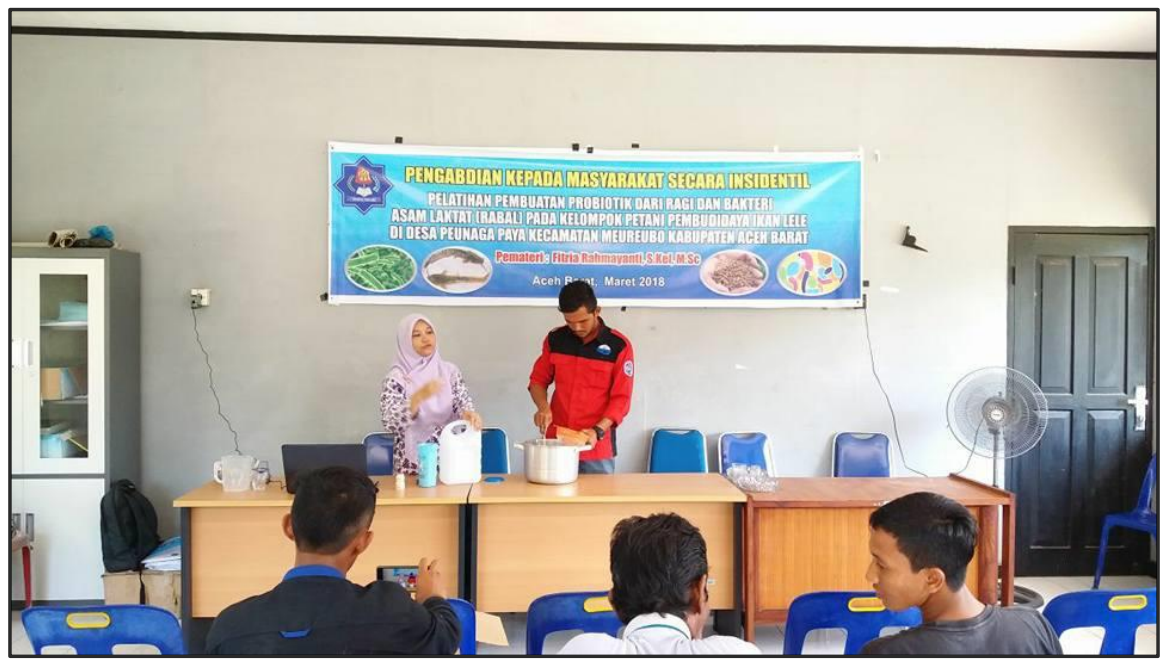

Gambar 2. Pembuatan Probiotik Sambil Berdiskusi dengan Peserta 


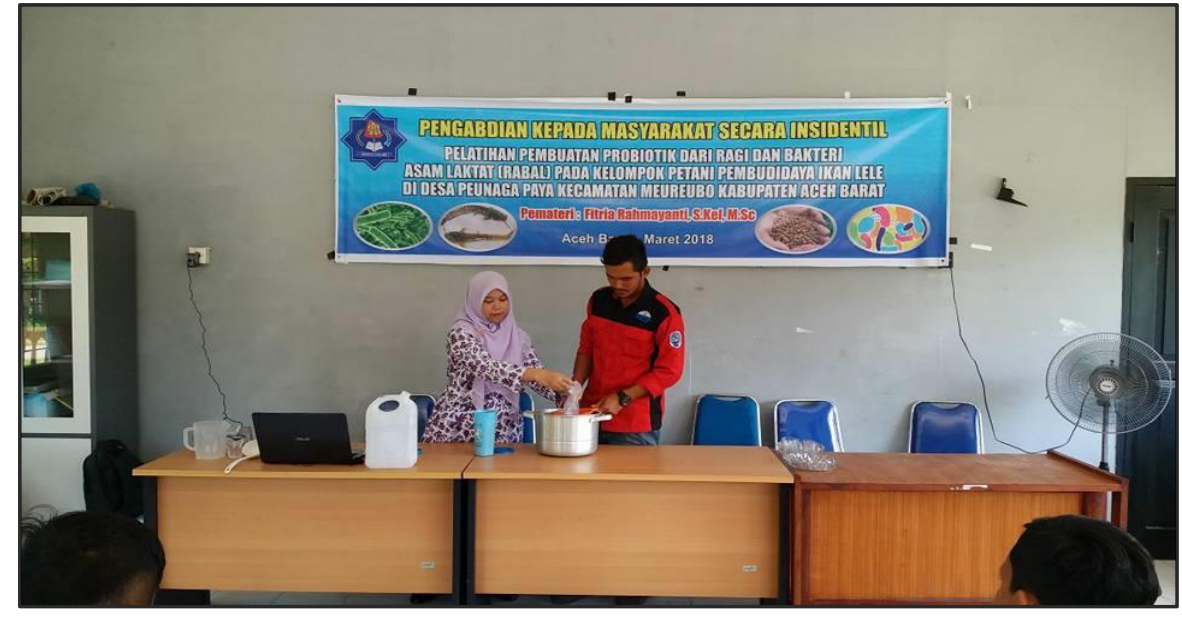

Gambar 3. Praktik Pembuatan Probiotik RABAL

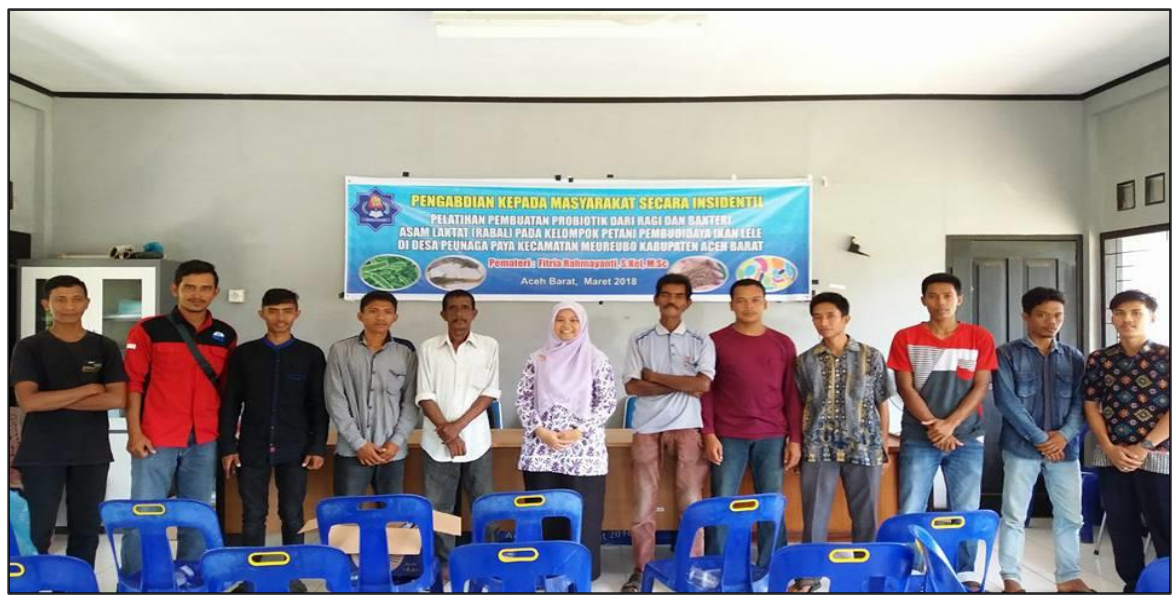

Gambar 4. Foto Bersama Diakhir Penyuluhan

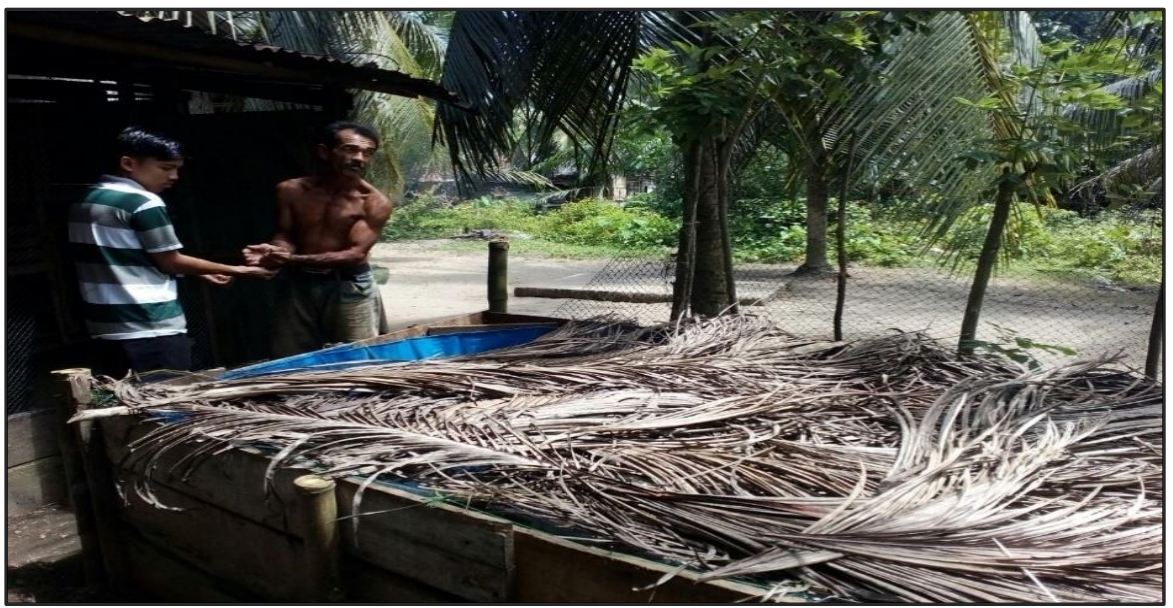

Gambar 5. Foto Aplikasi Probiotik RABAL Langsung di Kolam Masyarakat 